\title{
Antimicrobial effect of proteflazid extract on microflora of peri-implant areas in infectious and inflammatory complications after dental implantation
}

\author{
M. M. Ananieva, M. O. Faustova, Ya. O. Basarab, G. A. Loban' \\ Higher State Educational Institution of Ukraine “Ukrainian Medical Stomatological Academy”, Poltava
}

The purpose of this study was to investigate the proteflazid extraction antimicrobial action onto causative agents of infectious and inflammatory diseases occurring during dental implant placement.

Materials and methods. We studied clinical strains of Streptococcus sanguinis, Staphylococcus warneri and Kocuria kristinae, isolated from oral mucosa of patients who were diagnosed with peri-implant mucositis and peri-implantitis. The cultivation of strains was carried out by standard method. Final identification was carried out with an automatic bacteriological analyzer Viteck 2 compact bioMérieux (France) according to manufacturer's instructions. The sensitivity of derived strains to proteflazid and to $96 \%$ ethyl alcohol assessment was done by double serial dilutions according to the standard procedure.

Results. The clinical strains of Streptococcus sanguinis, Staphylococcus warneri and Kocuria kristinae were found to be sensitive to effects of proteflazid extract. K. kristinae was proven to be the least susceptible strain. But the clinical strain of Streptococcus sanguinis was found to be the most sensitive to proteflazid extract. $96 \%$ ethyl alcohol, which is a component of the extract, showed a bactericidal effect on the clinical strains in the study, but its minimal bactericidal concentration was significantly lower than minimal bactericidal concentration of the proteflazid extract.

Conclusions. The proteflazid extract can produce antimicrobial effect on the clinical strains of Streptococcus sanguinis, Staphylococcus warneri and Kocuria kristinae, which colonize the oral mucosa of patients with infectious and inflammatory complications following dental implant placement. Antimicrobial action of the proteflazid extract is much higher than action of $96 \%$ ethyl alcohol that confirms the direct antimicrobial action of flavonoids, which are components of the studied extract.

Key words: proteflazid extract, flavonoids, peri-implantitis, microbial sensitivity tests, antimicrobial agents.

\section{Zaporozhye} medical journal 2017; 19 (6), 809-812 DOI 10.14739/2310-1210 2017.6.115264

E-mail: anfila@ukr.net

Кмючові слова: екстракт протефлазиду, флавоноїди, периімплантит, чутливість мікроорганізмів, протимікробна дія.

Запорізький медичний журнал. - 2017. T. 19, № 6(105). C. 809-812

Результати. Встановлено, що клінічні штами Streptococcus sanguinis, Staphylococcus warneri та Kocuria kristinae виявились чутливими до дії екстракту протефлазиду. Доведено, що K. kristinae $€$ найменш чутливим до його дії штамом. Клінічний штам Streptococcus sanguinis виявився найчутливішим до дії екстракту протефрлазиду. 96 \% етиловий спирт, що є одним із компонентів екстракту, також чинив бактерицидну дію на клінічних штамах при дослідженні, але його мінімальна бактерицидна концентрація була значно нижчою, ніж мінімальна бактерицидна концентрація екстракту протефлазиду.

Висновки. Екстракт протефлазиду володіє протимікробною дією щодо клінічних штамів Streptococcus sanguinis, Staphylococcus warneri та Kocuria kristinae, які колонізують слизову оболонку порожнини рота хворих з інфекційно-запальними ускладненнями одонтоімплантації. Протимікробна дія екстракту протефрлазиду значно перевищує дію $96 \%$ етилового спирту, що підтверджує пряму протимікробну дію фрлавоноїдів, які входять до складу досліджуваного екстракту.

\section{Антимикробное действие экстракта протефказида на микрофлору периимплантатного участка при инфекционно-воспалительных осложнениях одонтоиплантации}

\section{М. Н. Ананьева, М. А. Фаустова, Я. А. Басараб, Г. А. Аобань}

Цель работы - определение противомикробного действия экстракта протефлазида на возбудителей инфекционно-воспалительных осложнений дентальной имплантации.

Материалы и методы. Объектом исследования являлись клинические штаммы Streptococcus sanguinis, Staphylococcus warneri и Kocuria kristinae, выделенные из слизистой оболочки полости рта у пациентов, которым был диагностирован периимплантатный мукозит и периимплантит. Культивировали штаммы согласно стандартной методике. Окончательная идентификация проводилась с помощью автоматического бактериологического анализатора Viteck 2 compact bioMérieux (Франция) в соответствии с инструкциями производителя. Оценку чувствительности полученных штаммов

Ключевые слова: экстракт протефлазияа, фкавоноиды, периимплантит, чувствительность микроорганизмов, противомикробное Аействие.

Запорожский медицинский журнал. - 2017.

T. 19, № 6(105). C. $809-812$ 
к протефрлазиду и 96 \% этиловому спирту выполняли методом двойных серийных разведений в соответствии со стандартной методикой.

Результаты. В результате исследования обнаружено, что клинические штаммы Streptococcus sanguinis, Staphylococcus warneri и Kocuria kristinae чувствительны к действию экстракта протесрлазида. Было доказано, что K. kristinae является наименее восприимчивым к его действию штаммом. Клинический штамм Streptococcus sanguinis оказался наиболее чувствительным кэкстракту протефлазида. В свою очередь, 96 \% этиловый спирт, который входит в состав исследуемого экстракта, также вызывал бактерицидное действие на клинические штаммы в ходе исследования, но его минимальная бактерицидная концентрация относительно них была значительно ниже, чем минимальная бактерицидная концентрация экстракта протефрлазида.

Выводы. Экстракт протесрлазида оказывает противомикробное действие на клинические штаммы Streptococcus sanguinis, Staphylococcus warneri и Kocuria kristinae, которые колонизируют слизистую оболочку полости рта у пациентов с инфекционно-воспалительными осложнениями дентальной имплантации. Противомикробное действие экстракта протефрлазида достоверно выше, чем действие 96 \% этилового спирта, что подтверждает прямое антимикробное действие фрлавоноидов, которые входят в состав изученного экстракта.

\section{Introduction}

In 60-70 years of the last century the flora of different human body biotopes was considered as saprophytic or opportunistic. Nowadays the scientists report a significant decline in population immunity worldwide that favours the augmentation and rapid spread of opportunistic infections. Environmental pollution, changing modes of diet, distress, and considerable spread of persistent human viral infections contributed to the problem mentioned above. It seemed paradoxically but among the etiological agents of severe infections some cases the oral microorganisms known as non-pathogenic played an important role [1]. There are numerous reports describing diseases caused by Streptococcus sanguinis, e.g. subacute infective endocarditis, abscesses of the brain, chronic aphthous stomatitis (associated with the L-forms of the pathogen) [2,3].

Staphylococcus warneri, unlike other coagulase-positive staphylococci does not possess such a wide spectrum of pathogenicity factors. However, it is known that the placement of braces, dental implants, removable and fixed orthopaedic appliances to correct dentition defects are often accompanied by colonizing their surfaces with pathogenic microflora, mainly with coagulase-negative staphylococci, followed by the development of opportunistic infections $[4,5]$. In addition, any breaches of the integrity of oral mucosa resulted from dental manipulations including in-office hygiene procedures, tooth preparation, etc., as well as overhanging edges of fillings and improperly fitted orthodontic appliances that can injure the gums and trigger the infectious process [5].

Based on detailed phylogenetic and chemotaxonomic analysis, Kocuria kristinae has been recently taken off the Genus Micrococcus and included on the Genus Kocuria [6]. Usually they are considered as non-pathogenic commensals of the human body, which quite extensively colonize the oral mucous membrane. However, having entered immunocompromised or diabetic hosts, they can act as opportunistic pathogens and cause bacteraemia, secondary bacterial infections that occur as consequences of primary viral infections $[6,7]$.

According to the relevant foreign reports, it is the representatives of normal oral microflora that can lead to infectious and inflammatory complications during implant placement, because their getting into the contact area with bone and impaired resistance of the organism can cause pathological processes in peri-implant tissues. In turn, the extensive use of antibiotics has resulted in antibiotic resistance that has been reported to be particularly pronounced among opportunistic species. Through the last decades facing the challenge of growing antibiotic resistance, scientists are seeking new options of antimicrobial agents, and thereupon the use of plant sources seems to be promising. This directs the attention toward the medicines, whose active ingredients are flavonoids of proteflazid extraction, and the approaches in developing new drugs to treat and prevent oral infectious and inflammatory diseases [8].

Thus, it is of great significance to study sensitivity of clinical stains of microorganisms that colonize the oral mucosa in cases of infectious and inflammatory diseases and can cause opportunistic infections under certain conditions, to the medicine mentioned above in terms of searching for new antibacterial agents.

The purpose of this study was to investigate the antimicrobial action of proteflazid extraction onto causative agents of infectious and inflammatory diseases occurring during dental implant placement.

\section{Materials and methods}

In this study we used proteflazid extract obtained from wild Calamagrostis epigeios L. and Deschampsia caespitosa L. by extracting stable molecular complexes of tricine, apigenin, luteolin, and quercetin [8]. This extract possesses specific antiviral properties against numerous viruses, and its direct action consists in the inhibition of DNA-virus synthesis in infected cells by DNA polymerase and thymidine kinase virus-specific enzymes activity reducing [9]. Moreover, proteflazid extract is known for its bactericidal action against some gram-positive and gram-negative microorganisms and fungi [8].

We studied 10 clinical strains of Streptococcus sanguinis, 10 clinical strains of Staphylococcus warneri and 10 clinical strains of Kocuria kristinae, isolated from oral mucosa of patients who were diagnosed with peri-implant mucositis and peri-implantitis. The cultivation of strains was carried out for 24-48 hours on tioglycol medium (I. I. Mechnikov Institute of Vaccines and Serums) by adding $1.5 \%$ agar medium "Dyfko", $5 \%$ blood and $0.5-1 \%$ yeast hydrolysate supplement to improve growth of microorganisms at the temperature $37^{\circ} \mathrm{C}$. Final identification was carried out with an automatic bacteriological analyzer Viteck 2 compact bioMérieux (France) according to manufacturer's instructions.

The sensitivity assessment of the derived strains to proteflazid and to $96 \%$ ethyl alcohol was done by double 
serial dilutions according to the standard procedure approved by the Order № 167 of the Ministry of Public Health of Ukraine on «On Approval of Training Guidance «Assessment of the sensitivity of microorganisms to antibiotics «, dated by April, 5, 2007 [10].

Each studied extract was diluted in the volume of $1 \mathrm{~cm}^{3}$ with final microorganism culture of approximately concentration $3 \times 10 \mathrm{CFU} / \mathrm{cm}^{3} .1 \mathrm{ml}$ of proteflazid solution contained the extract (1: 1) with at least $0.32 \mathrm{mg}$ of flavonoids in rutin equivalent and not less than $0.3 \mathrm{mg}$ of total carboxylic acids in malic acid equivalent; $96 \%$ ethyl alcohol was an excipient. For inoculation we used microbial suspension equivalent to 1.0 by McFarland Equivalence Standards, diluted 1/100 in saline, and then the concentration of microorganisms in this suspension was $3 \times 1010 \mathrm{CFU} / \mathrm{cm}^{3}$. Inoculum in a dose of $0.1 \mathrm{~cm}^{3}$ was brought into each test tube containing $1.0 \mathrm{~cm}^{3}$ of appropriate dilutions of process solution, and into a test tube with $1.0 \mathrm{~cm}^{3}$ of the broth medium without the extract, to have so-called «negative control». Inoculum was brought in the test tubes with dilutions immediately after preparation.

The test tubes were incubated in a normal atmosphere at the temperature $37^{\circ} \mathrm{C}$ for $20-24$ hours. Bactericidal proteflazid minimum concentration was identified by inoculating the microorganisms from the broth medium into the agar medium (State Research Institute of Food Resources, National Academy of Agricultural Sciences of Ukraine). Cultures of the microbial species were incubated in a normal atmosphere at a temperature $37^{\circ} \mathrm{C}$ for $20-24$ hours. To determine the growth of the microorganisms, the test tubes with the cultures were not evaluated in transmitted light, unlike the «negative» control, because the mixing of broth medium and the solution containing flavonoids causes the turbidity. By taking this into the account, we only determined minimum bactericidal concentration (MBC) of proteflazid by inoculating the microorganisms from broth medium into the agar medium.

\section{Results and discussion}

The clinical strains of Streptococcus sanguinis, Staphylococcus warneri and Kocuria kristinae were found to be sensitive to proteflazid extract effects. K. kristinae was proven to be the least susceptible strain, proteflazid MBC against this strain was $0.04 \mathrm{mg} / \mathrm{ml}$ flavonoids in rutin equivalent. MBC of the flavonoids extract against the clinical strain of Staphylococcus warneri was defined as much smaller and equalled to $0.02 \mathrm{mg} / \mathrm{ml}$ in rutin equivalent. But the clinical strain of Streptococcus sanguinis was found to be the most sensitive to proteflazid extract, and the strain was completely killed by the concentration of $0.01 \mathrm{mg} / \mathrm{ml}$ in rutin equivalent.

$96 \%$ ethyl alcohol, which was a component of the extract, did produce a bactericidal effect on the clinical strains in the study, but its MBC was significantly lower than MBC of the proteflazid extract (Fig. 1).

In this regard, the antimicrobial proteflazid extract effect can be mainly associated with the activity of flavonoids that this extract contains, rather than with the effect of $96 \%$ ethyl alcohol.

\section{Conclusions}

1. The proteflazid extract can produce antimicrobial effect on the clinical strains of Streptococcus sanguinis,

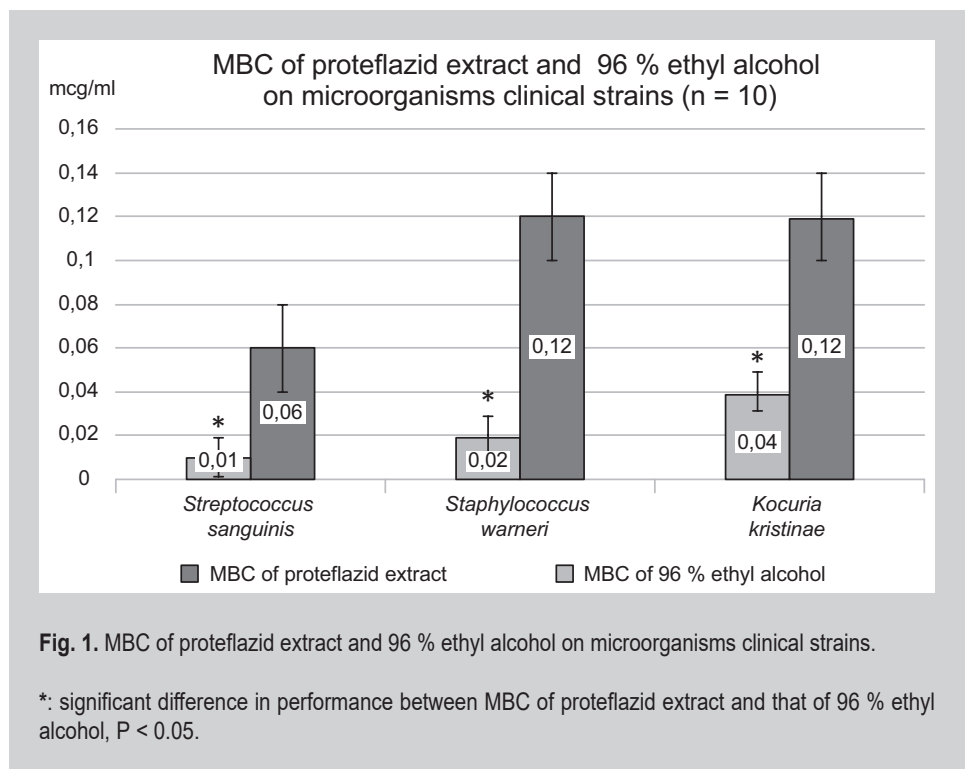

Staphylococcus warneri and Kocuria kristinae, which colonize the oral mucosa of patients with infectious and inflammatory complications following dental implant placement.

2. MBC of the proteflazid extract is much lower than MBC of $96 \%$ ethyl alcohol that confirms the direct antimicrobial action of flavonoids, which are components of the studied extract. This makes their use for the prevention and treatment of infectious and inflammatory complications, which might follow dental implant placement, quite promising.

Prospects for further research. The thorough study of antibacterial properties of flavonoids against anaerobic pathogens causing peri-implantitis is of great clinical significance.

\section{References}

[1] Kawamata, H., Hakata, K., Okubo, M., \& Uchida, D. (2015). Association of the oral bacteria with onset of the infective endocarditis. International Journal of Oral and Maxillofacial Surgery, 44, e240.

[2] DeSimone, D. C., DeSimone, C. V., Tleyjeh, I. M., de Sa, D. D. C., Anavekar, N. S., Lahr, B. D., \& Baddour, L. M. (2015). Association of mitral valve prolapse with infective endocarditis due to Viridans Group Streptococci. Clinical Infectious Diseases, 61(4), 623-625. doi: 10.1093/ cid/civ375.

[3] Duggal, S., \& Chugh, T. D. (2014). Pasteurella multocida: Cause of subdural and paranasal sinus abscesses in an adolescent. Journal of Pediatric Infectious Diseases, 9(2), 115-118. doi: 10.3233/JPI-140423.

[4] Bhardwaj, B., Bhatnagar, U. B., \& Conaway, D. G. (2016). An Unusual Presentation of Native Valve Endocarditis Caused by Staphylococcus warneri. Reviews in Cardiovascular Medicine, 17.

[5] Petrushanko, T. A., Tchereda, V. V., \& Loban, G. A. (2014). Skriningovaya diagnostika mikroe'kologicheskikh narushenij polosti rta [The screening diagnostic of micro ecological disorders of oral cavity]. Klinicheskaya laboratornaya diagnostika, 59(6), 48-50. [in Russian]

[6] Ahmed, N. H., Biswal, I., Roy, P., \& Grover, R. K. (2014). Kocuria kristinae, an unusual pathogen causing opportunistic infections in patients with malignancy. Indian journal of medical microbiology, 32(40), 456. doi: 10.4103/0255-0857.142232.

[7] Citro, R., Prota, C., Greco, L., Mirra, M., Masullo, A., Silverio, A et al. (2013). Kocuria kristinae endocarditis related to diabetic foot infection. Journal of medical microbiology, 62(6), 932-934. doi: 10.1099/ jmm.0.054536-0.

[8] Faustova, M. O., Ananieva, M. M., \& Basarab, Ya. O. (2016). Bakterytsydna ta funhitsydna aktyvnist ekstraktu proteflazydu shchodo muzeinykh shtamiv mikroorhanizmiv Staphylococcus aureus AT·SS 25923, Staphylococcus epidermidis AT·SS 14990, Escherichia coli AT·SS 25922 Streptococcus faecalis AT·SS 29212, Micrococcus luteus ATCC 4698, Candida albicans AT.SS10231. [Bactericidal and fungicidal activity of the extract on proteflazid museum strains Staphylococcus aureus ATCC 
25923, Staphylococcus epidermidis ATCC 14990, Escherichia coli ATCC 25922, Streptococcus faecalis ATCC 29212, Micrococcus luteus ATCC 4698, Candida albicans ATSS10231]. Aktualni problemy suchasno medytsyny, 16, 4(56), 72-74. [in Ukrainian].

[9] Kaminskyi, V. V., Shalko, M. N., Michailov, V. S., Lesnikova, M. V., Yashchenko, L. A., Grynevych, O. I., \& Broun, T. A. (2015). Ocenka e'ffektivnosti preparata Proteflazyd pry lechenii papillomavirusnoj infekcii: meta-analiz rezul'tatov mnogoletnikh klinicheskikh issledovanij [Evaluation of efficacy of Proteflazid in the treatment of HPV-infection: meta-analysis of long-term clinical trials results]. Medicinskie aspekty zdorov'ya zhenshchiny, 6(92), 5-14. [in Russian].

[10] Nakaz Ministerstva okhorony zdorovia Ukrayiny «Pro zatverdzhennia metodychnykh vkazivok «Vyznachennia chutlyvosti mikroorhanizmiv do antybakterial'nykh preparativ» vid 05.04.2007 r. №167 [Order №167 of the Ministry of Public Health of Ukraine on "On Approval of Training Guidance "Assessment of the sensitivity of microorganisms to antibiotics", April, 5, 2007]. Retrieved from: http//www.moz.gov.ua. [in Ukrainian].

\section{Information about authors:}

Ananieva M. M., MD, PhD, Lecturer, Department of Microbiology, Virology and Immunology, HSEEU “Ukrainian Medical

Stomatological Academy", Poltava.

Faustova M. O., MD, Lecturer, Department of Microbiology, Virology and Immunology, HSEEU "Ukrainian Medical Stomatological Academy", Poltava.

Basarab Ya. O., MD, Lecturer, Department of Microbiology, Virology and Immunology, HSEEU “Ukrainian Medical Stomatological Academy", Poltava.

Loban' G. A., MD, PhD, DSci, Head of the Department of Microbiology, Virology and Immunology, HSEEU “Ukrainian Medical Stomatological Academy", Poltava.

\section{Відомості про авторів:}

Ананьєва М. М., канд. меА. наук, викладач каф. мікробіології, вірусології та імунології, ВАНЗУ „Українська медична стоматологічна акалемія", м. Полтава.

Фаустова М. О., викладач каф. мікробіології, вірусології та імунології, ВАНЗУ „Українська медична стоматологічна академія", м. Полтава.

Басараб Я. О., викладач каф. мікробіології, вірусології та імунології, ВАНЗУ „Українська медична стоматологічна академія", м. Полтава.

лобань Г. А., А-р меА. наук, професор, зав. каф. мікробіології, вірусології та імунології, ВАНЗУ “Українська медична стоматологічна академія", м. Полтава.

\section{Сведения об авторах:}

Ананьева М. Н., канА. меА. наук, преподаватель каф. микробиологии, вирусологии и иммунологии, ВГузу "Украинская медицинская стоматологическая академия", г. Полтава.

Фаустова М. А., преподаватель каф. микробиологии, вирусологии и иммунологии, ВГУзУ «Украинская медицинская стоматологическая академия", г. Полтава.

Басараб Я. А., преподаватель каф. микробиологии, вирусологии и иммунологии, ВГУзУ «Украинская медицинская стоматологическая академия", г. Полтава.

^обань Г. А., А-р меА. наук, проф., зав. каф. микробиологии, вирусологии и иммунологии, ВГУзУ «Украинская меАицинская стоматологическая академия", г. Полтава.

Конфлікт інтересів: віАсутній.

Conflicts of Interest: authors have no conflict of interest to declare.

Надійшло Ао редакції / Received: 12.05.2017

Після Аоопрацювання / Revised: 22.05.2017

Прийнято Ао Аруку / Accepted: 22.06.2017 